\title{
Natural Product Rottlerin Derivatives Targeting Quorum Sensing
}

\author{
Dittu Suresh $^{1}$, Shekh Sabir ${ }^{1}$ (D), Tsz Tin Yu ${ }^{1}$ (D), Daniel Wenholz ${ }^{1}$, Theerthankar Das ${ }^{2}$, David StC. Black ${ }^{1, *(D)}$ \\ and Naresh Kumar ${ }^{1, *}$
}

check for updates

Citation: Suresh, D.; Sabir, S.; Yu, T.T.; Wenholz, D.; Das, T.; Black, D.S..; Kumar, N. Natural Product Rottlerin Derivatives Targeting Quorum Sensing. Molecules 2021, 26, 3745. https://doi.org/10.3390/

molecules 26123745

Academic Editor: Federica Belluti

Received: 20 May 2021

Accepted: 16 June 2021

Published: 19 June 2021

Publisher's Note: MDPI stays neutral with regard to jurisdictional claims in published maps and institutional affiliations.

Copyright: (c) 2021 by the authors. Licensee MDPI, Basel, Switzerland. This article is an open access article distributed under the terms and conditions of the Creative Commons Attribution (CC BY) license (https:/ / creativecommons.org/licenses/by/ $4.0 /)$.
1 School of Chemistry, The University of New South Wales, Sydney, NSW 2052, Australia; d.suresh@student.unsw.edu.au (D.S.); s.sabir@student.unsw.edu.au (S.S.); tsztin.yu@unsw.edu.au (T.T.Y.); d.wenholz@unsw.edu.au (D.W.)

2 Department of Infectious Diseases and Immunology, School of Medical Sciences, The University of Sydney, Sydney, NSW 2006, Australia; das.ashishkumar@sydney.edu.au

* Correspondence: d.black@unsw.edu.au (D.S.B.); n.kumar@unsw.edu.au (N.K.); Tel.: +61-29385-4698 (N.K.); Fax: +61-29385-6141 (N.K.)

\begin{abstract}
Rottlerin is a natural product consisting of chalcone and flavonoid scaffolds, both of which have previously shown quorum sensing (QS) inhibition in various bacteria. Therefore, the unique rottlerin scaffold highlights great potential in inhibiting the QS system of Pseudomonas aeruginosa. Rottlerin analogues were synthesised by modifications at its chalcone- and methylene-bridged acetophenone moieties. The synthesis of analogues was achieved using an established five-step synthetic strategy for chalcone derivatives and utilising the Mannich reaction at C6 of the chromene to construct morpholine analogues. Several pyranochromene chalcone derivatives were also generated using aldol conditions. All the synthetic rottlerin derivatives were screened for QS inhibition and growth inhibition against the related LasR QS system. The pyranochromene chalcone structures displayed high QS inhibitory activity with the most potent compounds, $\mathbf{8 b}$ and $\mathbf{8 d}$, achieving QS inhibition of $49.4 \%$ and $40.6 \%$ and no effect on bacterial growth inhibition at $31 \mu \mathrm{M}$, respectively. Both compounds also displayed moderate biofilm inhibitory activity and reduced the production of pyocyanin.
\end{abstract}

Keywords: natural products; rottlerin; pyranochromene chalcone; quorum sensing inhibitors; Pseudomonas aeruginosa

\section{Introduction}

Bacteria develop resistance due to the selective survival pressure applied by the mechanism of action of conventional antibiotics. Gram-negative bacteria are more resistant to antibiotics through some evolved mechanisms such as efflux pumps that eliminate the drugs, forming barriers that are more resistant to drug penetration, or producing enzymes that degrade drugs or through the formation of biofilm [1-3]. To overcome these resistance mechanisms, the concepts of bacterial biofilm formation and quorum sensing (QS) have attracted recent interest. As planktonic bacteria grow, small molecules known as autoinducers (AIs) are also synthesised intracellularly and released into the extracellular matrix. When the concentration of these AIs reaches a certain threshold, the bacteria reach a 'quorum', and the AIs bind to cognate receptors causing a signal transduction cascade that controls colony-wide gene expression. This type of intercellular bacterial communication, known as QS, is used to coordinate group behaviour and synchronise gene expression, including those responsible for biofilm formation as well as virulence [4,5].

Many natural products and their analogues have been tested for their potential as antibacterial agents. In particular, structures containing chalcones and flavonoids have stood out for their effectiveness as QS and biofilm inhibitors (Figure 1) [6]. Many traditional medicines and foods showing unique antibacterial properties have seen flavonoids as a recurring structural theme; one such naturally occurring flavonoid is quercetin. Quercetin 
has been reported to show activity against planktonic bacteria, as well as biofilm inhibition in both Streptococcus pneumoniae and P. aeruginosa [7,8]. Rutin and catechin are other examples of naturally occurring flavonoids that have been examined for QS activity. Rutin was found to significantly alter QS in Escherichia coli, inhibiting both the formation of biofilms and virulence genes [9], while catechin caused drastic negative effects in P. aeruginosa through the reduction of QS regulatory genes production (lasI, lasR, rhlI, and $r h l R$ ) as well as the inhibition of pyocyanin and biofilm formation [10]. Similarly, several natural chalcone structures have shown great potential in QS inhibition such as trans-benzylideneacetophenone (trans-chalcone) and licochalcone A. The trans-chalcone inhibited Streptococcus mutans biofilm formation while licochalcone showed an effective decrease in the expression of quorum-sensing genes in Salmonella typhimurium [11,12].

FLAVONOIDS

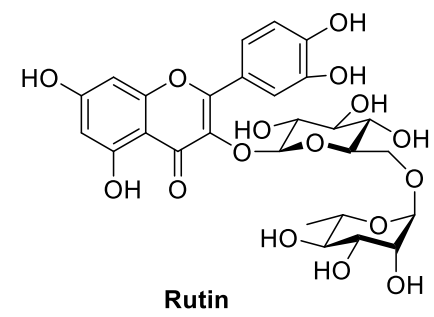<smiles>O=c1c(O)c(-c2ccc(O)c(O)c2)oc2cc(O)cc(O)c12</smiles><smiles>Oc1cc(O)c2c(c1)O[C@H](c1ccc(O)c(O)c1)[C@H](O)C2</smiles>
Quercetin Catechin

CHALCONES<smiles>O=C(CCc1ccc(O)cc1)c1c(O)cc(O)cc1O</smiles><smiles>O=C(/C=C/c1ccccc1)c1ccccc1</smiles>

FLAVONOIDS AND CHALCONES<smiles>CC(=O)c1c(O)c(C)c(O)c(Cc2c(O)c3c(c(C(=O)/C=C/c4ccccc4)c2O)OC(C)(C)C=C3)c1O</smiles><smiles>COc1cc(O)c(C(=O)/C=C/c2ccc(O)cc2)c2c1C=CC(C)(C)O2</smiles>

Figure 1. Flavonoid- and chalcone-containing natural products as anti-virulence and quorum sensing inhibitors.

Rottlerin is a natural compound isolated from kamala, a red powder that is produced on the surface of the fruit of the endangered medicinal plant Mallotus phillipinesis [13]. Rottlerin, which possesses both the characteristics of a chalcone and a flavonoid, is a potent protein kinase $C$ inhibitor with diverse biological activities. However, the limited availability of the natural molecule has resulted in restrictions to its development as a potential therapeutic lead. Recently, our group has reported an improved five-step large-scale synthesis of rottlerin [14] that can be completed in a time-efficient manner, thus creating an excellent opportunity to investigate its potential as a QS and biofilm inhibitor against Gramnegative bacteria, through the synthesis of analogues and developing structure-activity relationships. Moreover, we hypothesise that rottlerin analogues may target the quorum sensing systems in P. aeruginosa, because various other natural product derivatives with 
flavonoid and chalcone structures have shown QS and biofilm inhibition marking potential for rottlerin to be a QS inhibitor [6,15].

In line with our continuous efforts to develop novel synthetic and natural product analogues as antibacterial agents [16-18], in this paper, we report the synthesis of biologically interesting analogues of rottlerin and pyranochromene chalcones. The synthesised compounds have been evaluated for quorum sensing, biofilm and pyocyanin inhibition in P. aeruginosa.

\section{Results and Discussion}

\subsection{Analogue Synthesis}

The synthesis of rottlerin analogues followed the procedure previously described for the synthesis of rottlerin (Scheme 1) [14,19]. The synthesis involved the preparation of TBDMS-protected chromene 3 from 2,4,6-trihydroxyacetophenone 1 via mono TBDMSprotected acetophenone 2 followed by cyclisation with 3-methyl-2-butenal. Subsequently, chromene 3 underwent an aldol condensation reaction with benzaldehyde, resulting in the formation of chromene-chalcone 4.<smiles>CC(=O)c1c(O)cc(O)cc1O</smiles>

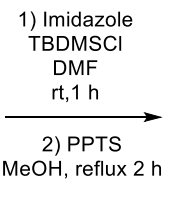

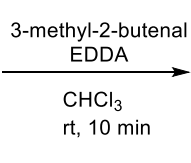

2
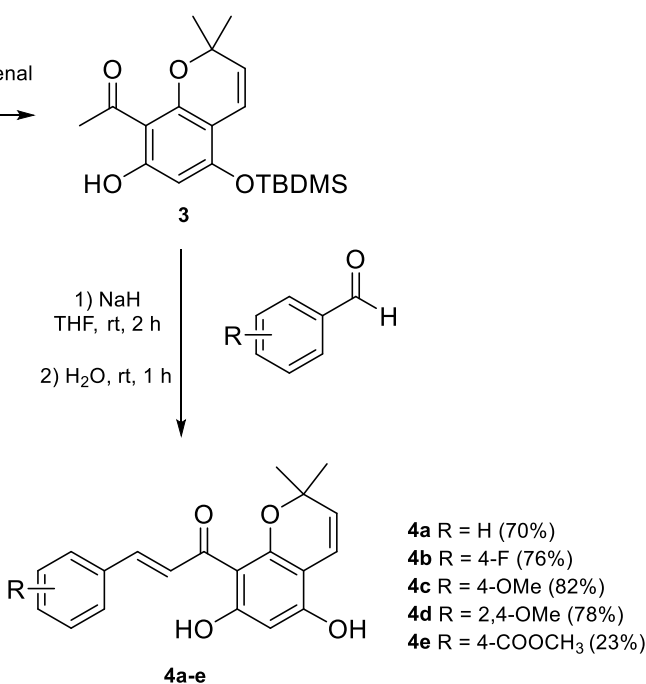

Scheme 1. Synthesis of chromene chalcones derivatives $4 a-\mathbf{e}$.

\subsection{Mannich Reactions at the C6 Chromene Position}

To understand the importance of the acetophenone group in rottlerin as well as to expand our library of compounds via Mannich reactions, the acetophenone group was replaced with a heterocyclic ring to produce a morpholine series of compounds $5 \mathbf{a}-\mathbf{d}$ (Scheme 2). These compounds were synthesised in low to moderate yields via the Mannich reaction using morpholine and paraformaldehyde to form an iminium ion that is then attacked by the electron rich aromatic ring of the chromene to form the methylene-bridged morpholine analogues. The ${ }^{1} \mathrm{H}$ NMR spectra revealed the presence of a broad singlet (overlapping signals) at 3.68 to $3.94 \mathrm{ppm}$ integrating for six protons, corresponding to the methylene bridge and morpholine ring $\mathrm{N}-\left(\mathrm{CH}_{2}\right)_{2}$ protons as well as a broad singlet at 2.70 to $2.80 \mathrm{ppm}$ integrating for four protons representing the other two $\mathrm{CH}_{2}$ groups of the morpholine ring. 


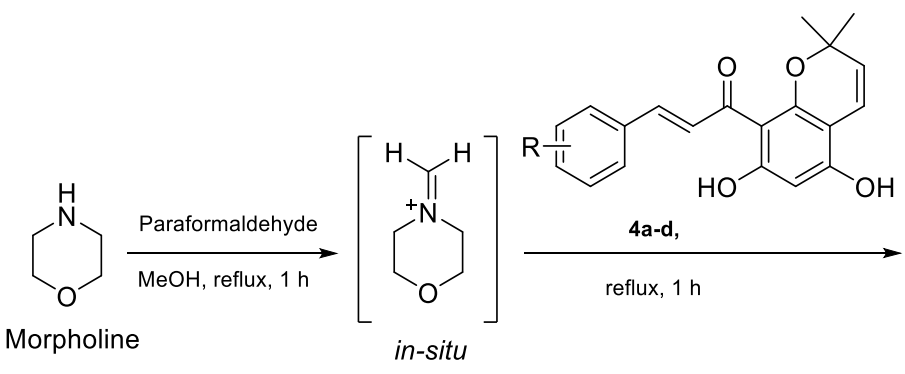<smiles>[R]c1ccc(/C=C/C(=O)c2c(O)c(CN3CCOCC3)c(O)c3c2OC(C)(C)C=C3)cc1</smiles>

$5 \mathbf{a} \mathrm{R}=\mathrm{H}(25 \%)$

5b $\mathrm{R}=4-\mathrm{F}(31 \%)$

$5 \mathrm{c} \mathrm{R}=4-\mathrm{OMe}(33 \%)$

5d $R=2,4-\mathrm{OMe}(35 \%)$

Scheme 2. Synthesis of morpholine derivatives of chromene chalcones $5 \mathbf{a}-\mathbf{d}$.

Following the successful synthesis of the morpholine analogues, several amino acids including tryptamine, phenylalanine and proline were trialed using the same reaction conditions. However, these reactions were unsuccessful and generated various complex mixtures in which the desired product could not be detected. It was believed that this may be due to the zwitterionic nature of amino acids, making their amine group less reactive. Hence, the reaction was repeated using phenylalanine methyl ester. However, a similar result was observed, and this suggested that it is the carboxylate/ester group that may be interfering with the reaction. Evidence for this was provided by a subsequent reaction of benzylamine with $4 \mathbf{a}$ under Mannich conditions that successfully yielded the final compound 6 in $12 \%$ isolated yield (Scheme 3 ). In the ${ }^{1} \mathrm{H}$ NMR spectrum of compound 6 (Figure S15), the two methylene bridges neighbouring the NH were observed at $3.85 \mathrm{ppm}$ and $4.12 \mathrm{ppm}$, while the five additional protons of the benzylamine ring were also consistent with the integration of the aromatic protons. Finally, HRMS analysis showed a $m / z$ peak at 442.2013 corresponding to $\mathrm{C}_{28} \mathrm{H}_{27} \mathrm{NO}_{4}$ (required 442.2013), which matched the structure of the benzylamino derivative 6 .<smiles>CC1(C)C=Cc2c(O)cc(O)c(C(=O)/C=C/c3ccccc3)c2OC1(C)C</smiles>

Scheme 3. Synthesis of benzylamine analogue of chromene chalcones 6 .

\subsection{Synthesis of Pyranochromenes}

Surprisingly, the synthesis of TBDMS-protected chromene 3 using pyridine as a base and a solvent instead of EDDA under reflux conditions resulted in the formation of an unexpected pyranochromene 7 (Scheme 4). It is believed that the high temperature reflux conditions caused a cleavage of the TBDMS-protecting group, resulting in the deprotected $\mathrm{OH}$ which further underwent cyclisation with 3-methyl-2-butenal to yield pyranochromene 7.

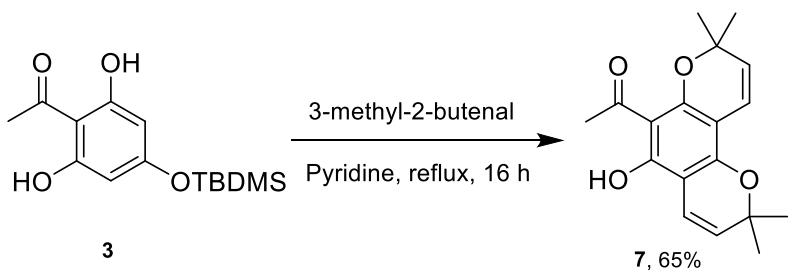

Scheme 4. Synthesis of pyranochromene 7. 
The ${ }^{1} \mathrm{H}$ NMR spectrum of bicyclic chromene 7 showed the absence of the TBDMS group and the aromatic $\mathrm{CH}$ peak, but the appearance of an extra singlet at $1.24 \mathrm{ppm}$ with an integration of six protons corresponding to the second dimethyl group. The spectrum also showed additional chromene $\mathrm{CH}=\mathrm{CH}$ peaks which merged together at around 5.07 to $5.27 \mathrm{ppm}$ and two doublets at $6.32 \mathrm{ppm}$ and $6.39 \mathrm{ppm}$. In comparison, the analysis of the ${ }^{1} \mathrm{H}$ NMR spectrum of TBDMS-protected chromene 3 clearly shows the tert-butyl group resonating as a singlet at $1.01 \mathrm{ppm}$ with an integration of nine protons and the silyl-dimethyl group resonating at $0.26 \mathrm{ppm}$ for six protons. Moreover, the presence of the aromatic $\mathrm{CH}$ peak at $5.96 \mathrm{ppm}$ is also observed.

\subsection{Synthesis of Pyranochromene Chalcones 8a-d}

Following the synthesis of the pyranochromene compound, it was used to form chalcone derivatives. As there was no TBDMS-protecting group which needed cleavage under $\mathrm{NaH}$ conditions, compounds 8a-d could be synthesised in moderate yields of 53 to $55 \%$ from pyranochromene 7 using the milder reaction condition ( $\mathrm{KOH}$ in $\mathrm{EtOH})$ and various substituted benzaldehydes with stirring at room temperature for $48 \mathrm{~h}$ (Scheme 5).

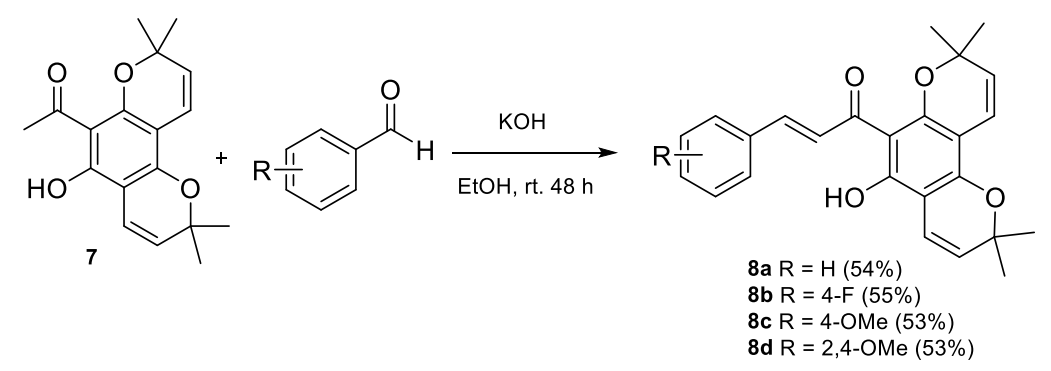

Scheme 5. Synthesis of pyranochromene chalcones $8 \mathbf{a}-\mathbf{d}$.

\subsection{QSI and Growth Inhibition Results}

The QSI activities of the synthesised compounds were evaluated against the LasR receptor by using the based $\mathrm{MH} 602 \mathrm{P}_{\text {las }} \mathrm{B}:: . g f p$ reporter strain of P. aeruginosa [20]. A known compound, furanone $\mathrm{C}-30$ (Fu C-30), was used as a positive control [21].

The concentration-dependent QSI activities of the synthesised compounds against the LasR receptor of $P$. aeruginosa are shown in Table 1. Amongst all the tested compounds, the two pyranochromene compounds 8a,d exhibited a promising QSI of $65.7 \%$ and $69.3 \%$, respectively, at $125 \mu \mathrm{M}$, and $49.4 \%$ and $40.6 \%$, respectively, at $31 \mu \mathrm{M}$. These compounds only possessed minimal $(<5 \%)$ bacterial growth inhibition at all tested concentrations.

Table 1. QSI inhibition assay on LasR system of P. aeruginosa using percentage of GFP fluorescence at $485 \mathrm{~nm}$ in $\mathrm{P}_{\text {las }} \mathrm{B}:: g f p$ (ASV). All measurements were taken from at least two independent tests carried out in triplicates with \pm standard deviation from mean.

\begin{tabular}{cccc}
\hline \multirow{2}{*}{ Compound } & $\mathbf{1 2 5} \boldsymbol{\mu M}$ & $\mathbf{6 3 \mu \mathbf { M }}$ & $\mathbf{3 1} \boldsymbol{\mu \mathbf { M }}$ \\
\cline { 2 - 4 } & \multicolumn{3}{c}{ Mean Percentage Inhibition } \\
\hline $\mathbf{5 a}$ & $28.0 \pm 4.5^{\mathrm{b}}$ & $26.8 \pm 6.7^{\mathrm{a}}$ & $30.0 \pm 2.7^{\mathrm{a}}$ \\
$\mathbf{5 b}$ & $40.3 \pm 3.8^{\mathrm{a}}$ & $27.4 \pm 10.2^{\mathrm{a}}$ & $13.8 \pm 10.0^{\mathrm{a}}$ \\
$\mathbf{5 c}$ & $29.1 \pm 16.7^{\mathrm{b}}$ & $48.8 \pm 13.3^{\mathrm{b}}$ & $57.9 \pm 3.6^{\mathrm{b}}$ \\
$\mathbf{5 d}$ & $64.0 \pm 3.4^{\mathrm{c}}$ & $47.9 \pm 5.1^{\mathrm{b}}$ & $42.6 \pm 0.9^{\mathrm{c}}$ \\
$\mathbf{6}$ & $40.8 \pm 4.2^{\mathrm{b}}$ & $24.3 \pm 3.2^{\mathrm{a}}$ & $24.6 \pm 1.1^{\mathrm{b}}$ \\
$\mathbf{8 a}$ & $66.3 \pm 6.9^{\mathrm{a}}$ & $52.7 \pm 5.8^{\mathrm{a}}$ & $39.4 \pm 3.3^{\mathrm{a}}$ \\
$\mathbf{8 b}$ & $65.7 \pm 3.7^{\mathrm{a}}$ & $58.1 \pm 9.4^{\mathrm{a}}$ & $49.4 \pm 1.5^{\mathrm{a}}$ \\
$\mathbf{8 c}$ & $59.5 \pm 0.6^{\mathrm{a}}$ & $46.5 \pm 6.1^{\mathrm{a}}$ & $35.7 \pm 3.3^{\mathrm{a}}$ \\
$\mathbf{8 d}$ & $69.3 \pm 10.5^{\mathrm{a}}$ & $58.4 \pm 7.3^{\mathrm{a}}$ & $40.6 \pm 4.0^{\mathrm{a}}$ \\
$\mathbf{F u 3 0}$ & $95.5 \pm 1.7^{\mathrm{c}}$ & $90.7 \pm 3.4^{\mathrm{c}}$ & $93.1 \pm 1.9^{\mathrm{b}}$ \\
\hline
\end{tabular}

a Growth inhibition less than $15 \% .{ }^{\mathrm{b}}$ Growth inhibition $>15 \%$ but $<30 \% .{ }^{\mathrm{c}}$ Growth inhibition greater than $30 \%$. 
Among three series (morpholine derivatives $\mathbf{5 a}-\mathbf{d}$, pyranochromene derivatives $\mathbf{8 a}-\mathbf{d}$ and benzylamino derivative $\mathbf{6}$ ) of compounds, pyranochromene derivatives $\mathbf{8 a}-\mathbf{d}$ exhibited superior QSI activities (59.5 to $69.3 \%$ ) with minimal (<15\%) bacterial growth inhibition at $125 \mu \mathrm{M}$. In terms of substitution at the terminal chalcone phenyl ring, the introduction of an electron-donating methoxy group or an electron-withdrawing fluorine atom had no significant effect on QSI activity at $125 \mu \mathrm{M}$. However, at the lower concentration of $31 \mu \mathrm{M}$, the fluoro-substituted analogue $\mathbf{8 b}$ displayed a slightly higher QSI activity of $49.4 \%$ than its parent compound $\mathbf{8 a}(\mathrm{QSI}=39.4 \%)$ and the methoxy-substituted analogues $\mathbf{8 c}-\mathbf{d}$ (QSI $=35.7 \%$ and $40.6 \%$, respectively). All pyranochromene derivatives $8 \mathbf{a}-\mathbf{d}$ also showed $0 \%$ growth inhibitory activity at $31 \mu \mathrm{M}$ concentration.

The morpholine compounds were more sensitive than the pyranochromene compounds to changes in the QSI activities as a result of chalcone modification. In terms of substitution at the terminal chalcone phenyl ring, the dimethoxy-substituted morpholinebearing analogue $5 \mathbf{d}$ possesses the highest QSI activity of $64.0 \%$ at $125 \mu \mathrm{M}$, and at a lower concentration of $31 \mu \mathrm{M}, 5 \mathrm{~d}$ possesses a QSI activity of $42.6 \%$. While QSI activities were expected to be concentration-dependent for all compounds, the opposite trend was observed for the mono-methoxy-substituted analogue $\mathbf{5 c}$ for which the QSI activity increases from $29.1 \%$ at $125 \mu \mathrm{M}$ to $57.9 \%$ at $31 \mu \mathrm{M}$. The reason of this is unclear and will require further investigation. Furthermore, when the morpholine moiety on compound 5a was replaced by a benzylamino group as in compound 6, the QSI activity increased from $28.0 \%$ to $40.8 \%$ at $125 \mu \mathrm{M}$, suggesting that the benzylamino group is favoured for QSI activity over the morpholine moiety at the high concentration of $125 \mu \mathrm{M}$. However, at the lower concentration of $31 \mu \mathrm{M}$, this relationship is less clear as compound $5 \mathrm{a}(\mathrm{QSI}=30.0 \%$ ) showed similar QSI activity to that of compound 6 (QSI $=24.6 \%$ ).

\subsection{Pyocyanin and Biofilm Inhibition Results}

The more potent compounds, $\mathbf{8 b}, \mathbf{d}$, which possess high QSI activities and low bacterial growth inhibition, were then selected to investigate their ability to inhibit pyocyanin production and biofilm formation (Figure 2). Both compounds only possess low to moderate antibacterial activity in the inhibition of the production of pyocyanin or formation of biofilm. Compound $\mathbf{8 d}$ was more potent than compound $\mathbf{8 b}$ with the percentage of pyocyanin inhibition and percentage inhibition of the formation of biofilm being $19 \%$ and $32 \%$, respectively. This is interesting as compound $\mathbf{8 b}$ was expected to possess a higher inhibitory activity in terms of pyocyanin production and biofilm formation because of its higher QSI activity. As other QS systems also contribute to pyocyanin production and biofilm formation, these results suggest that compound 8d probably affects other QS systems, causing a higher overall inhibitory activity compared to compound $\mathbf{8 b}$.

As QSI analogues derived from a natural product, the pyranochromene molecules $\mathbf{8 b}, \mathbf{d}$ in particular show great potential as they maintain above $40 \%$ inhibition of LasR QS at $31 \mu \mathrm{M}$ concentration. There is a considerable amount of LasR QS inhibitors derived from natural products. Several flavanoid molecules with similar structural characteristics to the rottlerin analogues (naringenin, eriodictyol and taxifolin) from the plant Combretum albiflorum have previously been reported for QS activity and only naringenin showed significant LasR QS inhibition; however, this was at a significantly higher $(4 \mathrm{mM})$ concentration in comparison [22]. Furthermore, $N$-decanoyl-L-homoserine benzyl ester and (phenylsulfinyl)alanine are other natural product derivatives which showed promise as QSI for LasR, with $29.67 \%$ inhibition at $100 \mu \mathrm{M}$ and up to $87.2 \%$ inhibition at $1 \mathrm{mM}$ respectively $[23,24]$. From these molecules, it is evident that the scaffolds for the pyranochromenes $\mathbf{8 b}$,d should be investigated further for their ability as QSIs at such a low concentration with no growth inhibition. Though there are also several other molecules which have been published that show greater effects, the pyranochromene rottlerine derivatives have the potential to be investigated further and be improved upon to the same levels. 
A P. aeruginosa PAO1 biofilm biomass inhibition

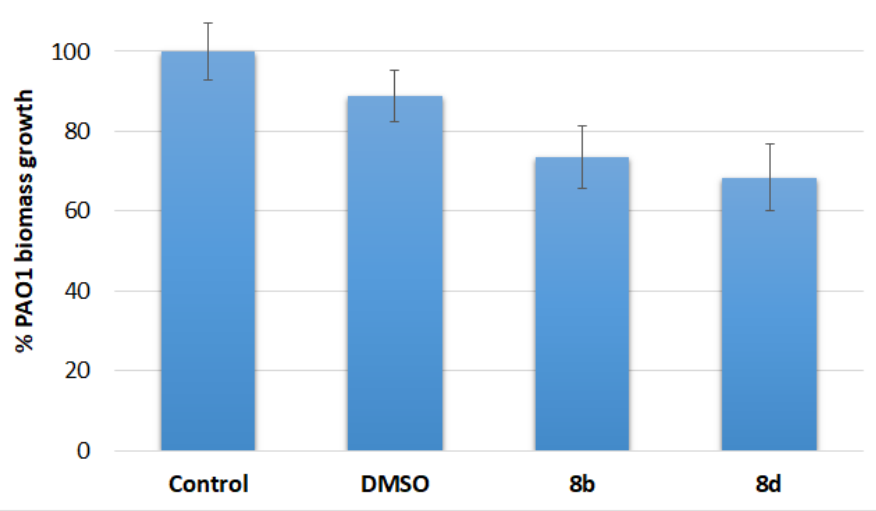

B P. aeruginosa PAO1 Pyocyanin inhibition

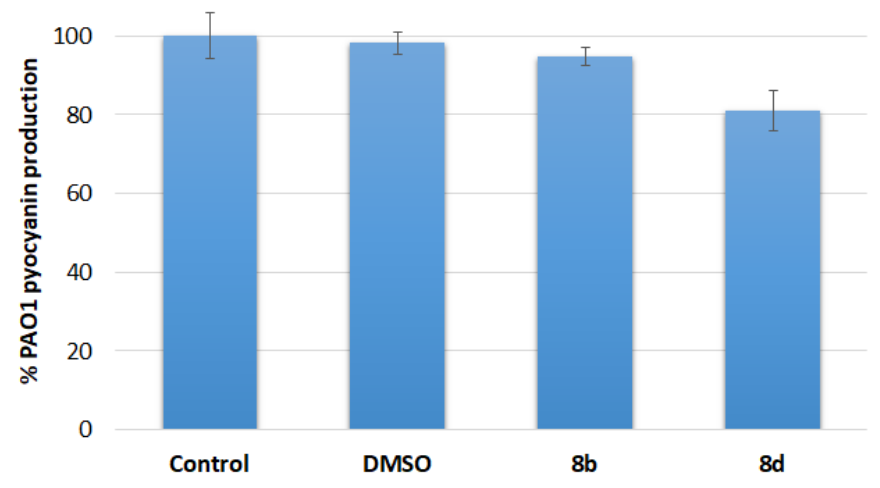

Figure 2. (A) Percentage biofilm mass inhibited by $\mathbf{8 b}$,d with blank as control and DMSO as comparison with P. aeruginosa (PAO1) planktonic cultures. (B) Percentage pyocyanin inhibited by $\mathbf{8 b}$ and $\mathbf{8 d}$ with respect to the DMSO control using P. aeruginosa (PAO1) planktonic cultures.

\section{Materials and Methods}

\subsection{Chemistry}

All reagents were bought commercially from Sigma Aldrich (Castle Hill, NSW, Australia), Alfa Aesar (Haverhill, MA, USA) and Combi-Blocks (San Diego, California, United States) and used without further purification. Anhydrous solvents were acquired from PureSolv MD Solvent Purification System. Room temperature (rt) refers to the ambient temperature $\left(25^{\circ} \mathrm{C}\right)$. Reactions were monitored by thin-layer chromatography (TLC, Merck PTY Ltd., Bayswater, Victoria, Australia) using precoated Merck silica gel 60 F254 plates and visualised using UV light (254 nm). Bruker Avance III 300 (Bruker Pty Ltd., Preston, Victoria, Australia) and Bruker Avance III HD 400 (Bruker Pty Ltd., Preston, Victoria, Australia) were used to obtain all ${ }^{1} \mathrm{H}$ and ${ }^{13} \mathrm{C}$ NMR spectra with the respective solvents using chemical shifts ( $\delta$ ) in parts per million (ppm). Multiplicities for NMR spectra have been assigned using singlet (s), doublet (d), doublet of doublet (dd), doublet of doublet of doublet (ddd), doublet of triplet (dt), triplet (t), quartet (q), doublet of quartet (dq), pentet $(\mathrm{p})$, hextet (h), septet (sept), multiplet (m), broad singlet (br) as necessary and coupling constants $(J)$ in Hertz $(\mathrm{Hz})$. Optimelt melting point apparatus was used for all measurement of all melting points, uncorrected. High-resolution mass spectra (HRMS, Thermo Scientific, Scoresby, Victoria, Australia) was conducted using Thermo LTQ Orbitrap XL instrument (Thermo Scientific, Scoresby, Victoria, Australia) under positive mode electrospray ionization by the UNSW Bioanalytical Mass Spectrometry Facility. Infrared (IR) spectra were recorded using a Cary 630 FTIR spectrometer (Agilent, Mulgrave, Victoria, Australia) fitted with a diamond-attenuated total reflectance (ATR) sample interface. Flash column chromatography was carried out using Grace Davisil LC60A silica. 


\subsection{General Synthetic Procedure A for (E)-Chalcone Chromene Derivatives (4a-e)}

TBDMS-protected chromene (3, 1.0 equivalent) was dissolved in anhydrous THF $(10 \mathrm{~mL})$ under an argon atmosphere and cooled to $0{ }^{\circ} \mathrm{C}$. A measure of $60 \% \mathrm{NaH}$ in mineral oil (5.0 equivalents) was added in small portions to the cooled solution over $5 \mathrm{~min}$. The mixture was then stirred for $5 \mathrm{~min}$ before the addition of the appropriate substituted benzaldehyde (two equivalents) and stirring continued at room temperature for $2 \mathrm{~h}$. Water $(12 \mathrm{~mL})$ was then added, and the reaction mixture was stirred for an additional $30 \mathrm{~min}$. After completion of the reaction, the product was extracted into EtOAc $(3 \times 30 \mathrm{~mL})$, combined organic extracts washed with brine $(30 \mathrm{~mL})$, dried over anhydrous sodium sulfate, and concentrated in vacuo. The crude mixture was purified using flash column chromatography on silica gel with $n$-hexane/EtOAc as the eluent to afford the product.

\subsection{General Synthetic Procedure B for Mannich Reactions at C6 Chromene Position (5a-d, 6)}

A solution of the appropriate amine or amino acid (1.2 equivalents) and paraformaldehyde (1.2 equivalents) were mixed in methanol and heated at reflux for $1 \mathrm{~h}$. The relevant (E)-chalcone chromene derivative (4a-e, 1.0 equivalent) was added and the reaction mixture was heated at reflux for a further $2 \mathrm{~h}$. After completing the reaction, the solvent was evaporated in vacuo and the resulting crude compound was purified using flash column chromatography on silica gel with $\mathrm{DCM} / \mathrm{MeOH}$ as the eluent to afford the product.

\subsection{Synthetic Procedure for Pyranochromene (7)}

3-Methyl-2-butenal ( $2.6 \mathrm{~mL}, 25.60 \mathrm{mmol})$ was added to a solution of $2(2.89 \mathrm{~g}, 10.20 \mathrm{mmol})$ in pyridine $(10 \mathrm{~mL})$ and the reaction mixture was heated at reflux for $16 \mathrm{~h}$. After completion of the reaction, the product was extracted into EtOAc $(3 \times 30 \mathrm{~mL})$, the combined organic extracts were washed with brine $(30 \mathrm{~mL})$, dried over anhydrous sodium sulfate, and concentrated in vacuo. The crude mixture was purified using flash column chromatography on silica gel with $n$-hexane/EtOAc (19:1) as the eluent to afford the product as a yellow crystalline solid $(2.00 \mathrm{~g}, 65 \%)$. mp 91.3 to $94.6{ }^{\circ} \mathrm{C} ;{ }^{1} \mathrm{H} \mathrm{NMR}\left(400 \mathrm{MHz}, \mathrm{CDCl}_{3}\right) \delta 14.00(\mathrm{~s}$, $1 \mathrm{H}), 6.65(\mathrm{~d}, J=10.0 \mathrm{~Hz}, 1 \mathrm{H}), 6.58(\mathrm{~d}, J=10.0 \mathrm{~Hz}, 1 \mathrm{H}), 5.47$ to $5.42(\mathrm{~m}, 2 \mathrm{H}), 2.66(\mathrm{~s}, 3 \mathrm{H}), 1.50$ $(\mathrm{s}, 6 \mathrm{H}), 1.44(\mathrm{~s}, 6 \mathrm{H}) ; 13 \mathrm{C} \mathrm{NMR}\left(101 \mathrm{MHz}, \mathrm{CDCl}_{3}\right) \delta 203.5,160.7,156.8,155.2,125.5,124.9$, 116.6, 116.3, 105.7, 102.5, 102.3, 33.4, 28.5, 28.1; IR (ATR): $v_{\max } 3042,2970,2703,1592 \mathrm{~cm}^{-1}$.

\subsection{General Synthetic Procedure C for Pyranochromene Chalcones (8a-d)}

The appropriate substituted benzaldehyde (1.2 equivalents) and $\mathrm{KOH}$ pellets (5.0 equivalents) were added to a solution of pyranochromene ( $7,1.0$ equivalent) in $\mathrm{EtOH}$ $(10 \mathrm{~mL})$. The reaction mixture was stirred at room temperature for $48 \mathrm{~h}$, and following the completion of the reaction, $\mathrm{EtOH}$ was evaporated in vacuo. Water $(10 \mathrm{~mL})$ was then added to the crude product and extracted using EtOAc $(3 \times 20 \mathrm{~mL})$. The combined organic extracts were washed with $2 \mathrm{M} \mathrm{HCl}(15 \mathrm{~mL})$ then brine $(15 \mathrm{~mL})$, dried over anhydrous sodium sulfate and concentrated in vacuo. The resulting product was purified using flash column chromatography on silica gel with $n$-hexane/EtOAc as the eluent to afford the product.

\subsection{Experimental Characterisation Data}

(E)-1-(5,7-Dihydroxy-2,2-dimethyl-2H-chromen-8-yl)-3-(4-fluorophenyl)prop-2-en-1-one (4b): The title compound was synthesised from TBDMS-protected chromene 3 ( $0.1 \mathrm{~g}$, $0.287 \mathrm{mmol})$ and 4 -fluorobenzaldehyde $(0.061 \mathrm{~mL}, 0.574 \mathrm{mmol})$ following general synthetic procedure $\mathrm{A}$. The product $4 \mathrm{~b}$ was eluted and obtained as an orange solid $(0.74 \mathrm{~g}, 0.218 \mathrm{mmol})$; mp 169.6 to $174.7^{\circ} \mathrm{C} ;{ }^{1} \mathrm{H}$ NMR $\left(400 \mathrm{MHz}, \mathrm{CDCl}_{3}\right) \delta 13.97(\mathrm{~s}, 1 \mathrm{H}), 8.01(\mathrm{~d}, J=15.6 \mathrm{~Hz}, 1 \mathrm{H})$, $7.73(\mathrm{~d}, J=15.6 \mathrm{~Hz}, 1 \mathrm{H}), 7.62$ to $7.54(\mathrm{~m}, 2 \mathrm{H}), 7.15$ to $7.06(\mathrm{~m}, 2 \mathrm{H}), 6.57(\mathrm{~d}, J=9.9 \mathrm{~Hz}$, $1 \mathrm{H}), 5.95(\mathrm{~s}, 1 \mathrm{H}), 5.50(\mathrm{~d}, J=9.9 \mathrm{~Hz}, 1 \mathrm{H}), 5.46(\mathrm{~s}, 1 \mathrm{H}), 1.55(\mathrm{~s}, 6 \mathrm{H}) ;{ }^{13} \mathrm{C}$ NMR $(101 \mathrm{MHz}$, CDCl3) $\delta 192.91,166.72,157.84,156.82,141.21,131.97,130.24,130.15,127.33,125.07,116.50$, 116.40, 116.18, 106.85, 102.37, 96.57, 78.40, 28.19; IR (ATR): $v_{\max } 3238,2967,2342,2120,1591$, $1504 \mathrm{~cm}^{-1}$; MS (+ESI): $m / z$ 341.1184, $\left[\mathrm{M}+\mathrm{H}^{+}, \mathrm{C}_{20} \mathrm{H}_{17} \mathrm{FO}_{4}\right.$ required $[\mathrm{M}+\mathrm{H}]^{+} 341.1184$. 
(E)-1-(5,7-Dihydroxy-2,2-dimethyl-2H-chromen-8-yl)-3-(4-methoxyphenyl)prop-2-en1-one (4c): The title compound was synthesised from TBDMS-protected chromene 3 ( $0.5 \mathrm{~g}$, $1.435 \mathrm{mmol})$ and 4-methoxybenzaldehyde $(0.35 \mathrm{~mL}, 2.87 \mathrm{mmol})$ following general synthetic procedure $\mathrm{A}$. The product $4 \mathrm{c}$ was obtained as an orange solid $(0.415 \mathrm{~g}, 82 \%) ; \mathrm{mp}$ 193.3-196. ${ }^{\circ} \mathrm{C} ;{ }^{1} \mathrm{H}$ NMR $\left(400 \mathrm{MHz}, \mathrm{CDCl}_{3}\right) \delta 14.15(\mathrm{~s}, 1 \mathrm{H}), 8.00(\mathrm{~d}, J=15.6 \mathrm{~Hz}, 1 \mathrm{H}), 7.77$ $(\mathrm{d}, J=15.6 \mathrm{~Hz}, 1 \mathrm{H}), 7.60$ to $7.52(\mathrm{~m}, 2 \mathrm{H}), 6.98$ to $6.87(\mathrm{~m}, 2 \mathrm{H}), 6.57(\mathrm{~d}, J=9.9 \mathrm{~Hz}, 1 \mathrm{H})$, $5.94(\mathrm{~s}, 1 \mathrm{H}), 5.49(\mathrm{~d}, J=9.9 \mathrm{~Hz}, 1 \mathrm{H}), 3.86(\mathrm{~s}, 3 \mathrm{H}), 1.56(\mathrm{~s}, 6 \mathrm{H})$; IR (ATR): $v_{\max } 3178,3122$, 2964, 2942, 2321, 2116, $1588 \mathrm{~cm}^{-1}$; MS (+ESI): $\mathrm{m} / z$ 353.1383, [M + H] $]^{+}, \mathrm{C}_{21} \mathrm{H}_{20} \mathrm{O}_{5}$ required $[\mathrm{M}+\mathrm{H}]^{+} 353.1384$.

(E)-1-(5,7-Dihydroxy-2,2-dimethyl-2H-chromen-8-yl)-3-(2,4-dimethoxyphenyl)prop-2-en1-one (4d): The title compound was synthesised from TBDMS-protected chromene 3 ( $0.4 \mathrm{~g}$, $1.148 \mathrm{mmol})$ and 2,4-dimethoxybenzaldehyde $(0.38 \mathrm{~g}, 2.296 \mathrm{mmol})$ following general synthetic procedure $\mathrm{A}$. The product $4 \mathrm{~d}$ was obtained as a dark orange solid $(0.342 \mathrm{mg}, 78 \%)$; mp 162.8 to $163.7^{\circ} \mathrm{C} ;{ }^{1} \mathrm{H}$ NMR $\left(300 \mathrm{MHz}, \mathrm{CDCl}_{3}\right) \delta 14.27(\mathrm{~s}, 1 \mathrm{H}), 8.13(\mathrm{~d}, J=15.7 \mathrm{~Hz}, 1 \mathrm{H})$, $8.02(\mathrm{~d}, J=15.7 \mathrm{~Hz}, 1 \mathrm{H}), 7.56(\mathrm{~d}, J=8.6 \mathrm{~Hz}, 1 \mathrm{H}), 6.60$ to $6.46(\mathrm{~m}, 3 \mathrm{H}), 5.94(\mathrm{~s}, 1 \mathrm{H}), 5.48(\mathrm{~d}$, $J=9.9 \mathrm{~Hz}, 1 \mathrm{H}), 3.89(\mathrm{~s}, 3 \mathrm{H}), 3.86(\mathrm{~s}, 3 \mathrm{H}), 1.54(\mathrm{~s}, 6 \mathrm{H}) ;{ }^{13} \mathrm{C} \mathrm{NMR}(101 \mathrm{MHz}, \mathrm{CDCl} 3) \delta 193.50$, $166.65,163.03,160.38,157.61,156.72,138.30,129.97,125.26,124.98,117.92,116.63,106.95$, $105.68,102.33,98.62,96.50,78.14,62.05,55.74,55.64,28.04 ;$ IR (ATR): $v_{\max } 3199,2962,2931$, 2168, $1602 \mathrm{~cm}^{-1}$; MS (+ESI): $m / z$ 383.1490, [M + H] $]^{+}, \mathrm{C}_{22} \mathrm{H}_{22} \mathrm{O}_{6}$ required $[\mathrm{M}+\mathrm{H}]^{+} 383.1489$.

Methyl(E)-4-(3-(5,7-dihydroxy-2,2-dimethyl-2H-chromen-8-yl)-3-oxoprop-1-en-1-yl) benzoate (4e): The title compound was synthesised from TBDMS-protected chromene 3 ( $0.1 \mathrm{~g}$, $0.327 \mathrm{mmol})$ and methy-4-formylbenzoate $(0.140 \mathrm{~g}, 0.854 \mathrm{mmol})$ following general synthetic procedure $\mathrm{A}$. The product $4 \mathrm{e}$ was obtained as a yellow solid $(0.028 \mathrm{~g}, 23 \%)$; $\mathrm{mp}$ 211.3-215.6 ${ }^{\circ} \mathrm{C} ;{ }^{1} \mathrm{H}$ NMR $\left(400 \mathrm{MHz}, \mathrm{DMSO}-d_{6}\right) \delta 13.86(\mathrm{~s}, 1 \mathrm{H}), 8.14(\mathrm{~d}, J=15.6 \mathrm{~Hz}, 1 \mathrm{H}), 8.10$ to $8.04(\mathrm{~m}, 2 \mathrm{H}), 7.74(\mathrm{~d}, J=15.6 \mathrm{~Hz}, 1 \mathrm{H}), 7.70$ to $7.62(\mathrm{~m}, 2 \mathrm{H}), 6.57(\mathrm{~d}, J=9.9 \mathrm{~Hz}, 1 \mathrm{H}), 5.95$ $(\mathrm{s}, 1 \mathrm{H}), 5.50(\mathrm{~d}, J=9.9 \mathrm{~Hz}, 1 \mathrm{H}), 3.94(\mathrm{~s}, 3 \mathrm{H}), 1.55$ (s, 6H); IR (ATR): $v_{\max } 3198,2973,2706$, 2304, 2107, 1931, 1719, $1601 \mathrm{~cm}^{-1}$; MS (+ESI): $\mathrm{m} / z$ 381.1331, $\left[\mathrm{M}+\mathrm{H}^{+}, \mathrm{C}_{22} \mathrm{H}_{20} \mathrm{O}_{6}\right.$ required $[\mathrm{M}+\mathrm{H}]^{+} 381.1333$.

(E)-1-(5,7-Dihydroxy-2,2-dimethyl-6-(morpholinomethyl)-2H-chromen-8-yl)-3phenylprop-2-en-1-one (5a): The title compound was synthesised from $4 \mathbf{a}(0.1 \mathrm{~g}, 0.31 \mathrm{mmol})$, paraformaldehyde $(0.011 \mathrm{~g}, 0.37 \mathrm{mmol})$ and morpholine $(0.032 \mathrm{~mL}, 0.37 \mathrm{mmol})$ following general synthetic procedure $\mathrm{B}$. The product $7 \mathrm{a}$ was obtained as an orange solid $(0.033 \mathrm{~g}$, 25\%); mp 131.2 to $134.5^{\circ} \mathrm{C} ;{ }^{1} \mathrm{H}$ NMR $\left(400 \mathrm{MHz}, \mathrm{CDCl}_{3}\right) \delta 8.13(\mathrm{~d}, J=15.7 \mathrm{~Hz}, 1 \mathrm{H}), 7.76$ $(\mathrm{d}, J=15.7 \mathrm{~Hz}, 1 \mathrm{H}), 7.64$ to $7.57(\mathrm{~m}, 2 \mathrm{H}), 7.46$ to $7.34(\mathrm{~m}, 3 \mathrm{H}), 6.63(\mathrm{~d}, J=9.9 \mathrm{~Hz}, 1 \mathrm{H})$, $5.47(\mathrm{~d}, J=9.9 \mathrm{~Hz}, 1 \mathrm{H}), 3.91$ to $3.68(\mathrm{~m}, 6 \mathrm{H}), 2.78(\mathrm{br}, 4 \mathrm{H}), 1.55(\mathrm{~s}, 6 \mathrm{H}) ;{ }^{13} \mathrm{C} \mathrm{NMR}(76 \mathrm{MHz}$, DMSO) $\delta 190.78,164.59,164.06,155.24,141.24,135.16,130.41,129.30,128.12,127.34,124.26$, 116.82, 103.43, 102.68, 98.87, 77.84, 65.51, 53.05, 51.93, 27.62 ; IR (ATR): $v_{\max } 2957,2846$, 2521, 2343, 2118, 1848, $1599 \mathrm{~cm}^{-1}$; MS (+ESI): $\mathrm{m} / z$ 422.1961, [M + H] ${ }^{+} . \mathrm{C}_{25} \mathrm{H}_{27} \mathrm{NO}_{5}$ required $[\mathrm{M}+\mathrm{H}]^{+} 422.1962$.

(E)-1-(5,7-Dihydroxy-2,2-dimethyl-6-(morpholinomethyl)-2H-chromen-8-yl)-3-(4fluorophenyl)prop-2-en-1-one (5b): The title compound was synthesised from $4 \mathrm{~b}(0.2 \mathrm{~g}$, $0.56 \mathrm{mmol})$, paraformaldehyde $(0.020 \mathrm{~g}, 0.68 \mathrm{mmol})$ and morpholine $(0.06 \mathrm{~mL}, 0.68 \mathrm{mmol})$ following general synthetic procedure $\mathrm{B}$. The product $5 \mathrm{~b}$ was obtained as an orange solid $(0.068 \mathrm{~g}, 31 \%)$; $\mathrm{mp} 148.2$ to $152.1{ }^{\circ} \mathrm{C} ;{ }^{1} \mathrm{H}$ NMR $\left(400 \mathrm{MHz}, \mathrm{CDCl}_{3}\right) \delta 8.04(\mathrm{~d}, J=15.6 \mathrm{~Hz}$, $1 \mathrm{H}), 7.72(\mathrm{~d}, J=15.6 \mathrm{~Hz}, 1 \mathrm{H}), 7.63$ to $7.54(\mathrm{~m}, 2 \mathrm{H}), 7.16$ to $7.06(\mathrm{~m}, 2 \mathrm{H}), 6.65(\mathrm{~d}, J=9.9 \mathrm{~Hz}$, $1 \mathrm{H}), 5.47(\mathrm{~d}, J=9.9 \mathrm{~Hz}, 1 \mathrm{H}), 3.94$ to $3.75(\mathrm{~m}, 6 \mathrm{H}), 2.80(\mathrm{br}, 4 \mathrm{H}), 1.54(\mathrm{~s}, 6 \mathrm{H}) ;{ }^{13} \mathrm{C}$ NMR $\left(101 \mathrm{MHz}, \mathrm{CDCl}_{3}\right) \delta 192.73,180.10,165.03,164.79,162.69,141.00,132.05,130.21,130.12$, $127.44,124.62$, 117.08, 116.39, 116.17, 105.40, 103.18, 99.02, 97.19, 78.36, 66.33, 52.62, 28.29; IR (ATR): $v_{\max } 2922,2854,2501,2343,2113,1810,1596 \mathrm{~cm}^{-1}$; MS (+ESI): $\mathrm{m} / \mathrm{z} 440.1865$, $[\mathrm{M}+\mathrm{H}]^{+} . \mathrm{C}_{25} \mathrm{H}_{26} \mathrm{FNO}_{5}$ required $[\mathrm{M}+\mathrm{H}]^{+} 440.1868$.

(E)-1-(5,7-Dihydroxy-2,2-dimethyl-6-(morpholinomethyl)-2H-chromen-8-yl)-3-(4methoxyphenyl)prop-2-en-1-one (5c).The title compound was synthesised from $4 \mathrm{c}(0.05 \mathrm{~g}$, $0.14 \mathrm{mmol})$, paraformaldehyde $(0.05 \mathrm{~g}, 0.17 \mathrm{mmol})$ and morpholine $(0.018 \mathrm{~mL}, 0.17 \mathrm{mmol})$ following general synthetic procedure $B$. The product $7 \mathrm{c}$ was obtained as an orange solid 
(0.02 g, 33\%); mp 143.3 to $146.2{ }^{\circ} \mathrm{C} ;{ }^{1} \mathrm{H}$ NMR $\left(400 \mathrm{MHz}, \mathrm{CDCl}_{3}\right) \delta 8.03(\mathrm{~d}, J=15.6 \mathrm{~Hz}, 1 \mathrm{H})$, $7.76(\mathrm{~d}, J=15.6 \mathrm{~Hz}, 1 \mathrm{H}), 7.60$ to $7.50(\mathrm{~m}, 2 \mathrm{H}), 6.98$ to $6.90(\mathrm{~m}, 2 \mathrm{H}), 6.64(\mathrm{~d}, J=9.9 \mathrm{~Hz}, 1 \mathrm{H})$, $5.47(\mathrm{~d}, J=9.9 \mathrm{~Hz}, 1 \mathrm{H}), 4.04$ to $3.69(\mathrm{~m}, 9 \mathrm{H}), 2.70$ (br, $4 \mathrm{H}), 1.55$ (s, 6H); IR (ATR): $v_{\max } 2962$, 2915, 2852, 2556, 1600, $1542 \mathrm{~cm}^{-1}$; MS (+ESI): $m / z$ 452.2065, $[\mathrm{M}+\mathrm{H}]^{+}, \mathrm{C}_{26} \mathrm{H}_{29} \mathrm{NO}_{6}$ required $[\mathrm{M}+\mathrm{H}]^{+} 452.2068$.

(E)-1-(5,7-Dihydroxy-2,2-dimethyl-6-(morpholinomethyl)-2H-chromen-8-yl)-3-(2,4dimethoxyphenyl)prop-2-en-1-one (5d). The title compound was synthesised from $4 \mathrm{~d}$ $(0.05 \mathrm{~g}, 0.13 \mathrm{mmol})$, paraformaldehyde $(0.05 \mathrm{~g}, 0.17 \mathrm{mmol})$ and morpholine $(0.018 \mathrm{~mL}$, $0.17 \mathrm{mmol}$ ) following general synthetic procedure $\mathrm{B}$. The product $7 \mathrm{~d}$ was obtained as an orange solid (0.021 g, 35\%); mp 139.5 to $142.7{ }^{\circ} \mathrm{C} ;{ }^{1} \mathrm{H}$ NMR (400 MHz, DMSO) $\delta 8.04$ to 7.88 $(\mathrm{m}, 2 \mathrm{H}), 7.58(\mathrm{~d}, J=8.3 \mathrm{~Hz}, 1 \mathrm{H}), 6.67(\mathrm{~d}, J=8.0 \mathrm{~Hz}, 2 \mathrm{H}), 6.53(\mathrm{~d}, J=9.9 \mathrm{~Hz}, 1 \mathrm{H}), 5.54(\mathrm{~d}$, $J=9.9 \mathrm{~Hz}, 1 \mathrm{H}), 3.89(\mathrm{~s}, 3 \mathrm{H}), 3.84(\mathrm{~s}, 3 \mathrm{H}), 3.79(\mathrm{~s}, 2 \mathrm{H}), 3.71$ to $3.62(\mathrm{~m}, 4 \mathrm{H}), 2.68$ to $2.58(\mathrm{~m}$, 4H), 1.49 (s, 6H); ${ }^{13} \mathrm{C}$ NMR (101 MHz, DMSO-d $d_{6} \delta 191.56,163.71,162.94,162.80,159.89$, $154.95,137.31,129.76,124.48,124.41,116.59,116.35,106.56,103.78,102.18,98.97,98.68,77.67$, 65.69, 55.93, 55.58, 53.17, 52.04, 27.44; IR (ATR): $v_{\max } 2923,2846,2614,2508,2343,2113,1869$, $1596 \mathrm{~cm}^{-1}$; MS (+ESI): $m / z$ 452.2173, $[\mathrm{M}+\mathrm{H}]^{+}, \mathrm{C}_{27} \mathrm{H}_{31} \mathrm{NO}_{7}$ required $[\mathrm{M}+\mathrm{H}]^{+} 482.2173$.

(E)-1-(6-((Benzylamino)methyl)-5,7-dihydroxy-2,2-dimethyl-2H-chromen-8-yl)-3phenylprop-2-en-1-one (6): The title compound was synthesised from $4 \mathbf{a}(0.05 \mathrm{~g}, 0.15 \mathrm{mmol})$, paraformaldehyde $(0.006 \mathrm{~g}, 0.18 \mathrm{mmol})$ and benzylamine $(0.019 \mathrm{~g}, 0.18 \mathrm{mmol})$ following the general synthetic procedure B. The product 8a was obtained as a yellow solid $(0.008 \mathrm{~g}) ; \mathrm{mp}$ 132.4 to $135.2{ }^{\circ} \mathrm{C} ;{ }^{1} \mathrm{H}$ NMR $\left(300 \mathrm{MHz}, \mathrm{CDCl}_{3}\right) \delta 8.15(\mathrm{~d}, J=15.7 \mathrm{~Hz}, 1 \mathrm{H}), 7.75(\mathrm{~d}, J=15.7 \mathrm{~Hz}$, $1 \mathrm{H}), 7.67$ to $7.56(\mathrm{~m}, 2 \mathrm{H}), 7.48$ to $7.27(\mathrm{~m}, 8 \mathrm{H}), 6.66(\mathrm{~d}, J=9.9 \mathrm{~Hz}, 1 \mathrm{H}), 5.46(\mathrm{~d}, J=9.9 \mathrm{~Hz}$, $1 \mathrm{H}), 4.13$ (s, 2H), 3.85 (s, 2H), 1.55 (s, 6H); IR (ATR): $v_{\max }$ 3158, 2957, 2546, 2321, 2112, 1910, $1592 \mathrm{~cm}^{-1}$; $\mathrm{MS}(+\mathrm{ESI}): \mathrm{m} / z$ 442.2013, $[\mathrm{M}+\mathrm{H}]^{+}, \mathrm{C}_{28} \mathrm{H}_{27} \mathrm{NO}_{4}$ required $[\mathrm{M}+\mathrm{H}]^{+} 442.2013$.

(E)-1-(5-Hydroxy-2,2,8,8-tetramethyl-2H,8H-pyrano [2,3-f]chromen-6-yl)-3-phenylprop-2en-1-one (8a): The title compound was synthesised from $7(0.05 \mathrm{~g}, 0.17 \mathrm{mmol})$, benzaldehyde $(0.02 \mathrm{~mL}, 0.21 \mathrm{mmol})$ and $\mathrm{KOH}$ pellets $(0.05 \mathrm{~g}, 0.85 \mathrm{mmol})$ following general synthetic procedure $\mathrm{C}$. The product $8 \mathrm{a}$ was obtained as an orange solid $(0.036 \mathrm{~g}, 54 \%) ; \mathrm{mp} 95.2-97.4{ }^{\circ} \mathrm{C}$; ${ }^{1} \mathrm{H}$ NMR $\left(400 \mathrm{MHz}, \mathrm{CDCl}_{3}\right) \delta 14.36(\mathrm{~s}, 1 \mathrm{H}), 8.10(\mathrm{~d}, J=15.6 \mathrm{~Hz}, 1 \mathrm{H}), 7.77(\mathrm{~d}, J=15.6 \mathrm{~Hz}$, $1 \mathrm{H}), 7.64$ to $7.57(\mathrm{~m}, 2 \mathrm{H}), 7.46$ to $7.34(\mathrm{~m}, 3 \mathrm{H}), 6.69(\mathrm{~d}, J=10.0 \mathrm{~Hz}, 1 \mathrm{H}), 6.62(\mathrm{~d}, J=10.0 \mathrm{~Hz}$, $1 \mathrm{H}), 5.52$ to $5.45(\mathrm{~m}, 2 \mathrm{H}), 1.55(\mathrm{~s}, 6 \mathrm{H}), 1.46(\mathrm{~s}, 6 \mathrm{H}) ;{ }^{13} \mathrm{C} \mathrm{NMR}\left(101 \mathrm{MHz}, \mathrm{CDCl}_{3}\right) \delta 193.08$, $164.25,161.62,156.37,142.22,135.82,130.19,129.11,128.40,127.77,125.55,124.93,116.75$, $116.40,102.78,78.47,78.44,54.67,28.57,28.25$; IR (ATR): $v_{\max } 3058,2969,2644,2342,2109$, 1733, $1580 \mathrm{~cm}^{-1}$; MS (+ESI): $m / z$ 389.1748, $[\mathrm{M}+\mathrm{H}]^{+}, \mathrm{C}_{25} \mathrm{H}_{24} \mathrm{O}_{4}$ required $[\mathrm{M}+\mathrm{H}]^{+} 389.1747$.

(E)-3-(4-Fluorophenyl)-1-(5-hydroxy-2,2,8,8-tetramethyl-2H,8H-pyrano[2,3-f]chromen6-yl)prop-2-en-1-one (8b):The title compound was synthesised from 7 (0.05 g, $0.17 \mathrm{mmol})$, 4-fluorobenzaldehyde $(0.023 \mathrm{~mL}, 0.21 \mathrm{mmol})$ and $\mathrm{KOH}$ pellets $(0.05 \mathrm{~g}, 0.85 \mathrm{mmol})$ following general synthetic procedure $\mathrm{C}$. The product $\mathbf{8 b}$ was obtained as an orange solid $(0.38 \mathrm{~g}$, 55\%); mp 121.6 to $125.7{ }^{\circ} \mathrm{C} ;{ }^{1} \mathrm{H}$ NMR $\left(400 \mathrm{MHz}, \mathrm{CDCl}_{3}\right) \delta 14.31$ (s, $\left.1 \mathrm{H}\right), 8.01$ (d, $J=15.6 \mathrm{~Hz}$, $1 \mathrm{H}), 7.72(\mathrm{~d}, J=15.6 \mathrm{~Hz}, 1 \mathrm{H}), 7.63$ to $7.53(\mathrm{~m}, 2 \mathrm{H}), 7.15$ to $7.06(\mathrm{~m}, 2 \mathrm{H}), 6.69(\mathrm{~d}, J=10.0 \mathrm{~Hz}$, $1 \mathrm{H}), 6.62(\mathrm{~d}, J=10.0 \mathrm{~Hz}, 1 \mathrm{H}), 5.52$ to $5.40(\mathrm{~m}, 2 \mathrm{H}), 1.54(\mathrm{~s}, 6 \mathrm{H}), 1.46(\mathrm{~s}, 6 \mathrm{H})$; IR (ATR): $v_{\max }$ 3056, 2969, 2343, 2116, 1883, $1584 \mathrm{~cm}^{-1}$; MS (+ESI): $m / z$ 407.1655, $[\mathrm{M}+\mathrm{H}]^{+}, \mathrm{C}_{25} \mathrm{H}_{23} \mathrm{FO}_{4}$ required $[\mathrm{M}+\mathrm{H}]^{+} 407.1653$.

(E)-1-(5-Hydroxy-2,2,8,8-tetramethyl-2H,8H-pyrano[2,3-f]chromen-6-yl)-3-(4-methoxyphenyl)prop-2-en-1-one (8c): The title compound was synthesised from 7 (0.05 g, $0.17 \mathrm{mmol})$, 4-methoxybenzaldehyde $(0.025 \mathrm{~mL}, 0.21 \mathrm{mmol})$ and $\mathrm{KOH}$ pellets $(0.05 \mathrm{~g}$, $0.85 \mathrm{mmol}$ ) following general synthetic procedure $\mathrm{C}$. The product $10 \mathrm{c}$ was obtained as a red solid (0.38 g, 53\%); mp 134.3 to $135.7 ;{ }^{1} \mathrm{H} \mathrm{NMR}\left(400 \mathrm{MHz}, \mathrm{CDCl}_{3}\right) \delta 8.00(\mathrm{~d}, J=15.6 \mathrm{~Hz}, 1 \mathrm{H})$, $7.76(\mathrm{~d}, J=15.6 \mathrm{~Hz}, 1 \mathrm{H}), 7.56(\mathrm{~d}, J=8.8 \mathrm{~Hz}, 2 \mathrm{H}), 6.94(\mathrm{~d}, J=8.8 \mathrm{~Hz}, 2 \mathrm{H}), 6.69(\mathrm{~d}, J=9.9 \mathrm{~Hz}$, $1 \mathrm{H}), 6.62(\mathrm{~d}, J=9.9 \mathrm{~Hz}, 1 \mathrm{H}), 5.50$ to $5.44(\mathrm{~m}, 2 \mathrm{H}), 3.85(\mathrm{~s}, 3 \mathrm{H}), 1.55(\mathrm{~s}, 6 \mathrm{H}), 1.46(\mathrm{~s}, 6 \mathrm{H})$; ${ }^{13} \mathrm{C}$ NMR $\left(101 \mathrm{MHz}, \mathrm{CDCl}_{3}\right) \delta 193.02,171.28,161.65,161.48,156.27,155.23,142.33,130.10$, $128.56,125.48,125.40,124.84,116.81,116.46,114.59,106.10,102.78,102.64,78.37,78.32,55.54$, 28.53, 28.24 ; IR (ATR): $v_{\max } 3084,2967,2931,2513,2322,2116,1814,1576 \mathrm{~cm}^{-1}$; MS (+ESI): $m / z 441.1668,[\mathrm{M}+\mathrm{Na}]^{+}, \mathrm{C}_{26} \mathrm{H}_{26} \mathrm{O}_{5}$ required $[\mathrm{M}+\mathrm{Na}]^{+} 441.1672$. 
(E)-3-(2,4-Dimethoxyphenyl)-1-(5-hydroxy-2,2,8,8-tetramethyl-2H,8H-pyrano[2,3f]chromen-6-yl)prop-2-en-1-one (8d): The title compound was synthesised from 7 ( $0.05 \mathrm{~g}$, $0.17 \mathrm{mmol}), 2$, 4 -dimethoxybenzaldehyde $(0.035 \mathrm{mg}, 0.21 \mathrm{mmol})$ and $\mathrm{KOH}$ pellets $(0.05 \mathrm{~g}$, $0.85 \mathrm{mmol})$ following general synthetic procedure $\mathrm{C}$. The product $8 \mathbf{d}$ was obtained as a red solid $(0.40 \mathrm{~g}, 53 \%) ; \mathrm{mp} 133.5$ to $138.4{ }^{\circ} \mathrm{C} ;{ }^{1} \mathrm{H}$ NMR $\left(300 \mathrm{MHz}, \mathrm{CDCl}_{3}\right) \delta 8.12(\mathrm{~d}, J=15.7 \mathrm{~Hz}$, $1 \mathrm{H}), 8.02(\mathrm{~d}, J=15.7 \mathrm{~Hz}, 1 \mathrm{H}), 7.56(\mathrm{~d}, J=8.6 \mathrm{~Hz}, 1 \mathrm{H}), 6.70(\mathrm{~d}, J=10.0 \mathrm{~Hz}, 1 \mathrm{H}), 6.61(\mathrm{~d}$, $J=10.0 \mathrm{~Hz}, 1 \mathrm{H}), 6.57$ to $6.51(\mathrm{~m}, 1 \mathrm{H}), 6.49$ to $6.45(\mathrm{~m}, 1 \mathrm{H}), 5.51$ to $5.42(\mathrm{~m}, 2 \mathrm{H}), 5.30(\mathrm{~s}, 1 \mathrm{H})$, $3.88(\mathrm{~s}, 3 \mathrm{H}), 3.86(\mathrm{~s}, 3 \mathrm{H}), 1.53(\mathrm{~s}, 7 \mathrm{H}), 1.45(\mathrm{~s}, 6 \mathrm{H}) ;{ }^{13} \mathrm{C} \mathrm{NMR}\left(76 \mathrm{MHz}, \mathrm{CDCl}_{3}\right) \delta 193.46$, $162.96,161.66,160.32,156.24,154.99,137.91,129.89,125.49,125.38,124.86,117.98,116.84$, 116.57, 106.23, 105.64, 102.76, 102.57, 98.61, 78.25, 78.19, 55.73, 55.63, 53.57, 28.51, 28.11; IR (ATR): $v_{\max } 3102,2970,2935,2342,2116,1736,1606 \mathrm{~cm}^{-1}$; MS (+ESI): $\mathrm{m} / z$ 449.1958, $[\mathrm{M}+\mathrm{H}]^{+}, \mathrm{C}_{27} \mathrm{H}_{28} \mathrm{O}_{6}$ required $[\mathrm{M}+\mathrm{H}]^{+} 449.1959$.

\subsection{Biological Assays}

\subsubsection{LasR QS and Growth Inhibition Assay}

The P. aeruginosa MH602 $\mathrm{P}_{\text {las }} \mathrm{B}:: g f p(\mathrm{ASV})$ reporter strain, which harbors a chromosomal fusion of the las $B$ promoter to an unstable $g f p$ gene and responds to its autoinducer OdDHL [25], was used to evaluate the QSI activity of the synthesised compounds on QS signalling. An overnight culture was prepared in Luria-Bertani (LB10) media supplemented with gentamycin $(40 \mu \mathrm{M})$. This culture was then diluted (1:100) in TSB/LB10 (4:1) medium supplemented with gentamycin $(40 \mu \mathrm{M})$ and $200 \mu \mathrm{L}$ aliquots were dispensed to 96-well plate flat-bottom wells (Costar). The culture was supplemented with varying concentrations of test compounds dissolved in DMSO, with the final concentration of test compounds being $125,62.5$ and $31.25 \mu \mathrm{M}$. Wells with bacterial culture but no compound were used as negative controls while wells supplemented with furanone C-30 (Fu C-30) were used as positive controls. The plates were incubated for $15 \mathrm{~h}$ at $37^{\circ} \mathrm{C}$ with shaking at $150 \mathrm{rpm}$. After incubation, the reading of fluorescence (excitation, $485 \mathrm{~nm}$; emission, $520 \mathrm{~nm}$ ) and cell growth (optical density (OD) at $600 \mathrm{~nm}$ ) was taken in a plate reader (FLUOstar Omega, BMG Labtech). A decrease in fluorescence corresponded to increased QSI and lowered activation of the QS system.

\subsubsection{Pyocyanin and Biofilm Inhibition Assay}

P. aeruginosa planktonic cultures of PAO1 were grown overnight at $37^{\circ} \mathrm{C}$ and $150 \mathrm{rpm}$ in Tryptone soya broth (TSB, Oxoid, Thermo Scientific, Scoresby, Victoria, Australia). A total of $200 \mu \mathrm{L}(0.1 \pm 0.02$ at OD 600nm) of bacterial cell density was added into a 96-well plate (Corning Corp, Corning, NY, USA) with the compounds $8 \mathrm{~b}$ and $8 \mathrm{~d}(50 \mu \mathrm{M})$ with 48 h of incubation to initiate biofilm formation. The controls used blank and DMSO/solvent to initiate biofilm formation; after $48 \mathrm{~h}$, PBS was used to wash the formed biofilms once, the 96-well plates were then stained with $200 \mu \mathrm{L} 0.1 \%(w / v)$ crystal violet $(\mathrm{CV})$ and incubated at $37^{\circ} \mathrm{C}$ and $150 \mathrm{rpm}$ for $1 \mathrm{~h}$. This was followed by three washes of PBS removing excess $\mathrm{CV}$, $15 \mathrm{~min}$ of drying at $37^{\circ} \mathrm{C}$ and dissolving in $80 \% \mathrm{v} / \mathrm{v}$ ethanol, then transferring into a new 96-well, where the biomass was quantified at OD $550 \mathrm{~nm}$. Using the blank as a control, the activity of compounds $\mathbf{8 b}$ and $\mathbf{8 d}$ were tested as a percentage decrease from the blank control and was also compared to the effect of DMSO by itself.

For pyocyanin quantification, planktonic cultures of $P$. aeruginosa PAO1 were grown overnight by inoculating a single colony of PAO1 from the tryptone soy agar plate in $5 \mathrm{~mL}$ tryptone soy broth (TSB) and incubating at $37^{\circ} \mathrm{C}$ and $100 \mathrm{rpm}$. After overnight growth, the bacterial cultures were further diluted in $5 \mathrm{~mL}$ of TSB to a $\mathrm{OD}_{600 \mathrm{~nm}}=0.2 \pm 0.02$. The diluted bacterial suspension was grown for $48 \mathrm{~h}\left(\right.$ at $37^{\circ} \mathrm{C}$ and $\left.100 \mathrm{rpm}\right)$ either in the presence or absence of DMSO and compounds $(50 \mu \mathrm{M}) 8 \mathrm{~b}$ and $8 \mathrm{~d}$. Afterwards, the planktonic cultures were transferred into sterile falcon tubes and centrifuged at $4500 \times \mathrm{g}$ for $10 \mathrm{~min}$ at $4{ }^{\circ} \mathrm{C}$. The PAO1 supernatant was then removed by pipetting and transferred into new falcon tubes, followed by the addition of chloroform to a dilution factor of $300 \mu \mathrm{L}$ of chloroform for every $1000 \mu \mathrm{L}$ of supernatant. The supernatant-chloroform mixture was vortexed for 
$5 \mathrm{~s}$ and centrifuged at $4500 \times \mathrm{g}$ for $10 \mathrm{~min}$ at $4{ }^{\circ} \mathrm{C}$. Chloroform separated the pyocyanin in the supernatant into a blue layer. The blue layer was carefully pipetted out into sterile falcon tubes and treated with $0.2 \mathrm{M}$ hydrochloric acid, to a ratio of 1:2 (i.e., one part of $0.2 \mathrm{M} \mathrm{HCl}$ to two parts of blue colour solution). The HCl-blue pyocyanin mixture was then immediately vortexed for $5 \mathrm{~s}$ and further centrifuged $\left(10 \mathrm{~min}, 4500 \times g: 4{ }^{\circ} \mathrm{C}\right)$. The resultant acidified pyocyanin appeared as a red/pink layer at the top, of which $200 \mathrm{uL}$ was aliquoted into a 96-well plate, and the absorbance was recorded at $\mathrm{OD}_{520 \mathrm{~nm}}$ using a plate reader. The pyocyanin extraction assay using chloroform- $\mathrm{HCl}$ was adopted from Essar et al. 1990 [26].

\section{Conclusions}

A library of nine rottlerin analogues was successfully designed and synthesised for targeting the QS system in P. aeruginosa. The Mannich reaction at the C6 of chromene was utilised for the generation of methylene-bridged morpholine analogues as well as benzylaminomethyl compound $\mathbf{6}$. Furthermore, the unexpected synthesis of the pyranochromene led to the synthesis of four promising pyranochromene chalcone analogues. The synthesised compounds were tested with the LasR receptor; the pyranochromene structures exhibited good LasR QSI activity for all derivatives while also displaying low bacterial growth inhibition and the most potent analogues were identified to be $\mathbf{8 b}, \mathbf{d}$ with $49 \%$ and $40 \%$ QSI at $31 \mu \mathrm{M}$. These two compounds were also tested for their effect on biofilm and pyocyanin inhibition, with $8 \mathrm{~d}$ presenting promising results of $19 \%$ and $32 \%$, respectively. Contrastingly, the morpholine analogues showed much lower activity, except for $\mathbf{5 d}$, which displayed undesirably high growth inhibition. Based on these results the chromene structure was identified to be crucial in maintaining good LasR-based QSI activity in conjunction with low bacterial growth inhibition in Gram-negative bacteria. Additionally, due to the effectiveness of the pyranochromene chalcones in LasR, analogues of these structures can be further developed towards examining SAR.

Supplementary Materials: The supplementary materials are available online. $1 \mathrm{H}$ and $13 \mathrm{C}$ NMR spectra of the compounds and Growth inhibition data (P. aeruginosa MH602).

Author Contributions: N.K. and D.S.B. planned and designed the experiments. T.T.Y. and T.D. provided the data from biology screening. D.S. and S.S. performed the chemistry experiments, analysed, and interpreted the data and wrote the paper. D.W. contributed to design of experiments and editing of paper. N.K. supported financially. All authors have read and agreed to the published version of the manuscript.

Funding: This work was supported by a Discovery Project from Australian Research Council grant (DP180100845).

Institutional Review Board Statement: Not applicable.

Informed Consent Statement: Not applicable.

Data Availability Statement: Data is contained within the article and Supplementary Materials.

Acknowledgments: The authors thank the NMR and BMSF facility, UNSW Sydney. The authors would like to acknowledge the University of Sydney, Australia.

Conflicts of Interest: The authors declare no conflict of interest.

Sample Availability: Not available.

\section{References}

1. D'Costa, V.M.; King, C.E.; Kalan, L.; Morar, M.; Sung, W.W.; Schwarz, C.; Froese, D.; Zazula, G.; Calmels, F.; Debruyne, R. Antibiotic resistance is ancient. Nature 2011, 477, 457-461. [CrossRef]

2. Blair, J.M.; Webber, M.A.; Baylay, A.J.; Ogbolu, D.O.; Piddock, L.J. Molecular mechanisms of antibiotic resistance. Nat. Rev. Microbiol. 2015, 13, 42-51. [CrossRef] [PubMed]

3. Frieri, M.; Kumar, K.; Boutin, A. Antibiotic resistance. J. Infect. Public Health 2017, 10, 369-378. [CrossRef]

4. Galloway, W.; Hodgkinson, J.; Bowden, S.D.; Welch, M.; Spring, D. Quorum Sensing in Gram-Negative Bacteria: Small-Molecule Modulation of AHL and Al-2 Quorum Sensing Pathways. Chem. Rev. 2011, 111, 28-67. [CrossRef] 
5. Ng, W.; Bassler, B. Bacterial Quorum-Sensing Network Architectures. Annu. Rev. Genet. 2009, 43, 197-222. [CrossRef] [PubMed]

6. Silva, L.; Zimmer, K.; Macedo, A.; Trentin, D. Plant Natural Products Targeting Bacterial Virulence Factors. Chem. Rev. 2016, 116, 9162-9236. [CrossRef] [PubMed]

7. Ouyang, J.; Sun, F.; Feng, W.; Sun, Y.; Qiu, X.; Xiong, L.; Liu, Y.; Chen, Y. Quercetin is an effective inhibitor of quorum sensing, biofilm formation and virulence factors in Pseudomonas aeruginosa. J. Appl. Microbiol. 2016, 120, 966-974. [CrossRef] [PubMed]

8. Wang, J.; Song, M.; Pan, J.; Shen, X.; Liu, W.; Zhang, X.; Li, H.; Deng, X. Quercetin impairs Streptococcus pneumoniae biofilm formation by inhibiting sortase A activity. J. Cell Mol. Med. 2018, 22, 6228-6237. [CrossRef]

9. Peng, L.-Y.; Yuan, M.; Cui, Z.-Q.; Wu, Z.-M.; Yu, Z.-J.; Song, K.; Tang, B.; Fu, B.-D. Rutin inhibits quorum sensing, biofilm formation and virulence genes in avian pathogenic Escherichia coli. Microb. Pathog. 2018, 119, 54-59. [CrossRef]

10. Vandeputte, O.M.; Kiendrebeogo, M.; Rajaonson, S.; Diallo, B.; Mol, A.; El Jaziri, M.; Baucher, M. Identification of Catechin as One of the Flavonoids from Combretum albiflorum Bark Extract That Reduces the Production of Quorum-Sensing-Controlled Virulence Factors in Pseudomonas aeruginosa PAO1. Appl. Environ. Microbiol. 2009, 76, 243-253. [CrossRef]

11. Wallock-Richards, D.J.; Marles-Wright, J.; Clarke, D.J.; Maitra, A.; Dodds, M.; Hanley, B.; Campopiano, D.J. Molecular basis of Streptococcus mutans sortase A inhibition by the flavonoid natural product trans-chalcone. Chem. Commun. 2015, 51, 10483-10485. [CrossRef]

12. Somayyeh, H.; Habib Dastmalchi, S.; Malahat, A.; Taghi, Z.-S. Anti-quorum sensing effects of licochalcone A and epigallocatechin3-gallate against Salmonella Typhimurium isolates from poultry sources. Vet. Res. Forum 2020, 11, 273-279. [CrossRef]

13. Furusawa, M.; Ido, Y.; Tanaka, T.; Ito, T.; Nakaya, K.I.; Ibrahim, I.; Ohyama, M.; Iinuma, M.; Shirataka, Y.; Takahashi, Y. Novel, complex flavonoids from Mallotus philippensis (kamala tree). Helv. Chim. Acta 2005, 88, 1048-1058. [CrossRef]

14. Hong, K.K.C.; Ho, K.K.K.; Bhadbhade, M.; Ball, G.E.; Black, D.S.; Kumar, N. The Mosaic of Rottlerin: The Sequel. J. Nat. Prod. 2019, 82, 1190-1199. [CrossRef]

15. Fleitas Martínez, O.; Cardoso, M.H.; Ribeiro, S.M.; Franco, O.L. Recent Advances in Anti-virulence Therapeutic Strategies with a Focus on Dismantling Bacterial Membrane Microdomains, Toxin Neutralization, Quorum-Sensing Interference and Biofilm Inhibition. Front. Cell. Infect. Microbiol. 2019, 9, 74. [CrossRef] [PubMed]

16. Sabir, S.; Yu, T.T.; Kuppusamy, R.; Almohaywi, B.; Iskander, G.; Das, T.; Willcox, M.D.P.; Black, D.S.; Kumar, N. Novel Seleno- and Thio-Urea Containing Dihydropyrrol-2-One Analogues as Antibacterial Agents. Antibiotics 2021, 10, 321. [CrossRef]

17. Sabir, S.; Suresh, D.; Subramoni, S.; Das, T.; Bhadbhade, M.; Black, D.S.; Rice, S.A.; Kumar, N. Thioether-linked dihydropyrrol2-one analogues as PqsR antagonists against antibiotic resistant Pseudomonas aeruginosa. Bioorg. Med. Chem. 2021, 31, 115967. [CrossRef]

18. Sabir, S.; Subramoni, S.; Das, T.; Black, D.S.; Rice, S.A.; Kumar, N. Design, Synthesis and Biological Evaluation of Novel Anthraniloyl-AMP Mimics as PQS Biosynthesis Inhibitors against Pseudomonas aeruginosa Resistance. Molecules 2020, 25, 3103. [CrossRef]

19. Hong, K.K.C.; Ball, G.E.; Black, D.S.; Kumar, N. The Mosaic of Rottlerin. J. Org. Chem. 2015, 80, 10668. [CrossRef]

20. Manefield, M.; Rasmussen, T.; Henzter, M.; Andersen, J.; Steinberg, P.; Kjelleberg, S.; Givskov, M. Halogenated furanones inhibit quorum sensing through accelerated LuxR turnover. Microbiology 2002, 148, 1119-1127. [CrossRef] [PubMed]

21. He, Z.; Wang, Q.; Hu, Y.; Liang, J.; Jiang, Y.; Ma, R.; Tang, Z.; Huang, Z. Use of the quorum sensing inhibitor furanone C-30 to interfere with biofilm formation by Streptococcus mutans and its luxS mutant strain. Int. J. Antimicrob. Agents 2012, 40, 30-35. [CrossRef] [PubMed]

22. Vandeputte, O.M.; Kiendrebeogo, M.; Rasamiravaka, T.; Stévigny, C.; Duez, P.; Rajaonson, S.; Diallo, B.; Mol, A.; Baucher, M.; el Jaziri, M. The flavanone naringenin reduces the production of quorum sensing-controlled virulence factors in Pseudomonas aeruginosa PAO1. Microbiology 2011, 157, 2120-2132. [CrossRef]

23. Cady, N.C.; McKean, K.A.; Behnke, J.; Kubec, R.; Mosier, A.P.; Kasper, S.H.; Burz, D.S.; Musah, R.A. Inhibition of biofilm formation, quorum sensing and infection in Pseudomonas aeruginosa by natural products-inspired organosulfur compounds. PLoS ONE 2012, 7, e38492. [CrossRef] [PubMed]

24. Yang, Y.-X.; Xu, Z.-H.; Zhang, Y.-Q.; Tian, J.; Weng, L.-X.; Wang, L.-H. A New Quorum-Sensing Inhibitor Attenuates Virulence and Decreases Antibiotic Resistance in Pseudomonas aeruginosa. J. Microbiol. 2012, 50, 987-993. [CrossRef]

25. Hentzer, M.; Riedel, K.; Rasmussen, T.B.; Heydorn, A.; Andersen, J.B.; Parsek, M.R.; Rice, S.A.; Eberl, L.; Molin, S.; Høiby, N.; et al. Inhibition of quorum sensing in Pseudomonas aeruginosa biofilm bacteria by a halogenated furanone compound. Microbiology 2002, 148, 87-102. [CrossRef] [PubMed]

26. Essar, D.W.; Eberly, L.; Hadero, A.; Crawford, I.P. Identification and characterization of genes for a second anthranilate synthase in Pseudomonas aeruginosa: Interchangeability of the two anthranilate synthases and evolutionary implications. J. Bacteriol. 1990, 172, 884-900. [CrossRef] 